\title{
MONOCLONAL ANTIBODIES AGAINST AN OUTER MEMBRANE PROTEIN FROM PATHOGENIC LEPTOSPIRA
}

\section{Charli Beatriz Lüdtke ${ }^{1}$; Mariana Loner Coutinho ${ }^{1}$; Sandra Denise Dorneles Jouglard ${ }^{1}$; Cecília Nunes Moreira ${ }^{1}$; Cláudia Hartleben Pinho Fernandes ${ }^{1}$; Claudiomar Soares Brod ${ }^{2}$; David A. Haake ${ }^{3,4}$; Albert Icksang Ko ${ }^{5,6}$; Odir Antonio Dellagostin ${ }^{1}$; José Antonio Guimarães Aleixo ${ }^{1 *}$}

${ }^{1}$ Centro de Biotecnologia, Universidade Federal de Pelotas, Pelotas, RS, Brasil. ${ }^{2}$ Centro de Controle de Zoonoses, Universidade Federal de Pelotas, Pelotas, RS, Brasil. ${ }^{3}$ Division of Infectious Diseases, Veterans Affairs Greater Los Angeles Healthcare System, UCLA School of Medicine, Los Angeles, CA, United States. ${ }^{4}$ Department of Medicine, UCLA School of Medicine, Los Angeles, CA, United States. ${ }^{5}$ Centro de Pesquisa Gonçalo Moniz, Fundação Oswaldo Cruz, Salvador, BA, Brasil. ${ }^{6}$ Division of International Medicine and Infectious Diseases, Weill Medical College of Cornell University, New York, NY, United States.

This paper corresponds to an "extended abstract" selected for oral presentation in the $22^{\text {nd }}$ Brazilian Congress of Microbiology, held in Florianópolis, SC, Brazil, in November 17-20, 2003

\begin{abstract}
Two hybridomas secreting monoclonal antibodies (MAbs) that react with a lipoprotein (LipL32) of the outer membrane of pathogenic Leptospira were obtained. For hybridoma production, spleen cells from BALB/c mice imunized with recombinant LipL32 (rLipL32) were fused to SP2/O-Ag14 cells, selected in HAT medium and screened in an indirect ELISA. One MAb produced was of the IgG2b isotype and the other was an IgM. MAbs specificity was confirmed by indirect ELISA and immunoblotting using purified rLipL32 and whole-cell antigen preparations from Escherichia coli (E. coli) expressing LipL32 and from pathogenic and nonpathogenic serovars. Both Mabs reacted with most of the pathogenic serovars tested and none reacted with non-pathogenic Leptospira. The MAbs described have potential for use in diagnostic tests for leptospirosis.
\end{abstract}

Key words: leptospirosis, monoclonal antibodies, LipL32.

\section{INTRODUCTION}

Leptospirosis is an infectious disease common to animals and humans that is caused by pathogenic bacteria of the genus Leptospira. Diagnosis of leptospirosis usually requires laboratory confirmation because clinical symptoms are similar to other acute febrile diseases such as viral hepatitis, typhoid fever, meningitis, influenza, and dengue (5). Current laboratory confirmation of leptospirosis is based mainly on the demonstration of a significant or rising serum antibody titer using tests that include microscopic and macroscopic agglutination, and ELISA (8). A problem with this diagnostic approach is the low sensitivity of serological tests in the acute phase of the disease since a specific antibody response become detectable only 7 to 10 days after infection. Moreover, confirmation of diagnosis based on results of serological tests often is difficult because of the fact that some individuals show anti-Leptospira antibodies for years after recovery from the acute infection (9).

Improvement of laboratory diagnosis of the disease has been attempted by detection of leptospiral antigens in clinical material from either humans or animals using methods such as immunofluorescence (2), radioimmunoassay and enzymelinked immunosorbent assay (1), polymerase chain reaction (PCR) (4), and immunomagnetic capture combined to PCR (11). However, the immunological techniques for antigen detection

*Corresponding author. Mailing address: Centro de Biotecnologia, Universidade Federal de Pelotas. Campus Universitário do Capão do Leão, s/n 96019-900, Pelotas, RS, Brazil. 
lack specificity and PCR can be affected by inhibitory substances from the samples. Monoclonal antibodies (MAbs) directed against surface antigens of pathogenic Leptospira would be useful for the development of more specific assays. In this paper we report on the use of a recombinant outer membrane protein for production of MAbs that react only with pathogenic serovars of Leptospira. The data suggest that the MAbs could be useful in the development of specific immunoassays for detection of Leptospira in biological fluids and tissues.

\section{MATERIALS AND METHODS}

\section{Leptospira Serovars and Culture Conditions}

The leptospiral serovars used in this study were obtained from the Centro de Controle de Zoonoses (Universidade Federal de Pelotas, RS, Brazil). Leptospires were grown at $29^{\circ} \mathrm{C}$ in Ellinghausen-McCullough-Johnson-Harris (EMJH) medium (Difco Laboratories, Detroit, MI, USA) supplemented with 20\% rabbit serum. The organisms were maintained by weekly subculture in liquid EMJH medium.

\section{Recombinant Leptospira Antigen}

The lip 32 gene, obtained by PCR using the DNA from Leptospira interrogans as template, was cloned into the pAE expression vector that allows fusion of the protein with a 6 xHis tag. This plasmid was used to transform E. coli BL21 (DE3). Purification of the protein was accomplished by affinity chromatography with Ni-NTA resin using the QIA EXPRESSIONIST Kit (Qiagen), following manufacturer's instructions. The eluate was then dialyzed against PBS and glycine $0.1 \%, \mathrm{pH} 8.0$, for approximately $16 \mathrm{~h}$ at $4^{\circ} \mathrm{C}$. Protein in the final preparation was quantified by the Bradford method (3).

\section{Production of Monoclonal Antibodies}

The protocols used to establish the hybridomas and to produce the Mabs were those described in Antibodies: A Laboratory Manual (6). Briefly, six-week-old female BALB/c mice were initially injected IP with 100 ug of rLipL32 in Freund's complete adjuvant. Booster doses were given 2 and 4 weeks after the first immunization and the spleens removed 3 to 4 days after the last dose. Immunization efficacy was evaluated through an indirect ELISA using rLipL32 as antigen. Spleen cells from mouse showing the highest ELISA titer were fused with $\mathrm{Sp} 2 / \mathrm{O}$ myeloma cells in the presence of polyethylene glycol. The hibridomas were plated on 96 well microtiter plates at a concentration of $2 \times 10^{5}$ cells/well and selected in DMEM-HAT supplemented with $20 \%$ fetal bovine serum. The supernatants of wells showing hybridoma growth were screened for antigenspecific antibodies in the indirect ELISA using rLipL32 and rFaeG fimbrial protein from Escherichia coli as antigens. Hybridomas producing anti-rLipL32 specific antibodies were cloned twice by the limiting dilution technique and retested in the ELISA. Wells that showed good reactivity were expanded in large culture flasks to obtain culture supernatants for further testing and to prepare frozen cell stocks. Mab class and sub-class determination was made with a double-antibody sandwich ELISA isotyping kit (Calbiochem, San Diego, CA, USA). Culture supernatants were stored at $-20^{\circ} \mathrm{C}$ and hybridomas were frozen at $-70^{\circ} \mathrm{C}$ in fetal bovine serum containing $10 \%$ DMSO and stored in liquid nitrogen.

\section{Monoclonal Antibodies Specificities}

Whole cell antigens from serovars of pathogenic and nonpathogenic Leptospira and from a strain of Leptonema illini (Table 1) were used for testing Mabs specificities by indirect ELISA and immunoblotting. Antigens were prepared with cells from 7-day cultures which were harvested by centrifugation $(15,000 \times \mathrm{x}$, for $30 \mathrm{~min})$ at $4^{\circ} \mathrm{C}$ and washed twice in PBS $(0.01 \mathrm{M}$, $\mathrm{pH}$ 7.2). The cells were resuspended in PBS, counted in a PetroffHausser chamber, and the concentration adjusted to approximately $10^{9}$ cells per $\mathrm{ml}$. The cells were then killed $\left(56^{\circ} \mathrm{C}\right.$, overnight) and stored at $-20^{\circ} \mathrm{C}$.

For indirect ELISA, wells of microtiter plates (Nunc PolySorp, Nalge Nunc International, Rochester, NY, USA) were sensitized overnight at $4^{\circ} \mathrm{C}$ with $50 \mathrm{ml}$ of the cell suspensions in PBS. The wells were washed three times with PBS containing $0.5 \%$ Tween 20 (PBS-T) to remove unbound cells, $50 \mathrm{ml}$ of hybridoma spent culture supernatants were added and the plates were incubated for $1 \mathrm{~h}$ at $37^{\circ} \mathrm{C}$. Myeloma supernatant was added to serve as negative control. After another series of three washes, $50 \mathrm{ml}$ of a 1:1000 dilution of goat anti-mouse Ighorseradish peroxidase (Sigma, Saint Louis, MO, USA) in PBST was added to each well and incubated as above. Excess conjugate was removed by washing five times with PBST and $50 \mathrm{ml}$ of a solution of enzyme substrate/chromogen $\left(\mathrm{H}_{2} \mathrm{O}_{2} /\right.$ ortophenilenodiamine) in citrate-phosphate buffer $\mathrm{pH}$ 5.0. The reaction was allowed to take place in the dark for 10 minutes and optical density read at $450 \mathrm{~nm}$ in an ELISA reader (Multiskan MCC/340, Titertek Instruments, Huntsville, AL, USA). Wells containing rLipL32 protein and a cell suspension of Escherichia coli LB 21 treated as above were used as positive and negative controls, respectively.

For immunoblotting, antigens from cell suspensions were separated by SDS-PAGE (7) and transferred to a nitrocelulose membrane (12). Membrane was then blocked with a $3 \%$ BSA solution in PBS and reacted with the hybridoma supernatants. After washing, the membrane was incubated with a goat antimouse Ig-horseradish peroxidase conjugate (Sigma). Bands were visualized after the addition of substrate/chromogen solution $\left(\mathrm{H}_{2} \mathrm{O}_{2} / 3,3\right.$ ' diaminobenzidine). Lanes with $\mathrm{rLipL} 32$ protein and Escherichia coli LB21 were used as positive and negative controls, respectively. 


\section{RESULTS AND DISCUSSION}

This report describes the production and initial characterization of two Mabs that react with LipL32, a major leptospiral outer membrane protein expressed only in pathogenic serovars. The Mabs, one of the IgG2b isotype (1D9) and the other an IgM (1F9), were tested for immunoreactivity with several Leptospira serovars in indirect ELISA and immunoblotting (Table 1 and Fig. 1). The two Mabs reacted in both systems with all pathogenic serovars tested, except for sejroe, and showed no reaction with non-pathogenic Leptospira or related bacteria. Since MAbs reacted with different serovars from serogroup Sejroe, the absence of reaction with serovar sejroe could be either due to expression of a different protein or lack of gene expression. An attempt to

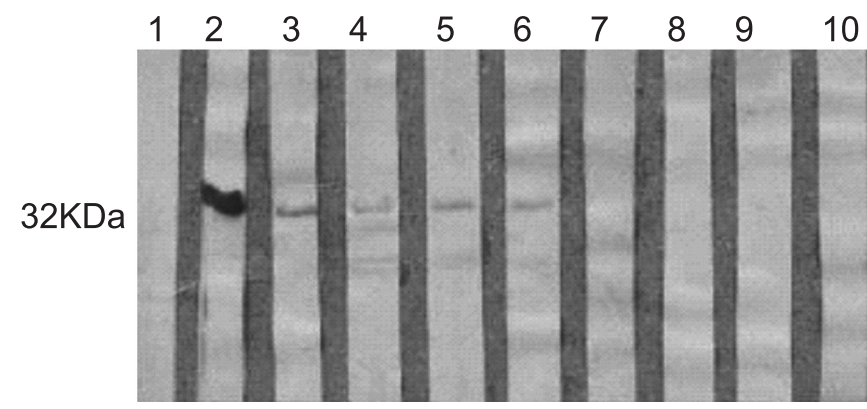

Figure 1. Illustrative immunoblotting results of MAbs reactions against different Leptospira serovars. (1) Molecular weight standards; (2) LipL32; (3) butembo; (4) hardjo; (5) canícola; (6) icterohaemorrhagae; (7) sejroe; (8) patoc; (9) Leptonema illini; (10) Escherichia coli BL21. MAb used: 1D9.

Table 1. Reactivities of Mabs anti-LipL32 with different serovars of Leptospiras in indirect ELISA and immunoblotting.

\begin{tabular}{|c|c|c|c|c|c|}
\hline \multirow[t]{2}{*}{ SEROGROUP } & \multirow[t]{2}{*}{ SEROVARS } & \multicolumn{2}{|c|}{ OD ELISA } & \multicolumn{2}{|c|}{ Immunoblotting } \\
\hline & & 1D9 & $1 \mathrm{~F} 9$ & 1D9 & $1 \mathrm{~F} 9$ \\
\hline \multirow[t]{2}{*}{ Australis } & australis & 0.303 & 0.268 & + & + \\
\hline & bratislava & 0.3145 & 0.298 & + & + \\
\hline \multirow[t]{3}{*}{ Autumnalis } & autumnalis & 0.226 & 0.198 & + & + \\
\hline & butembo & 0.312 & 0.301 & + & + \\
\hline & rachmati & 0.181 & 0.104 & + & + \\
\hline \multirow[t]{2}{*}{ Ballum } & castellonis & 0.410 & 0.401 & + & + \\
\hline & ballum & 0.288 & 0.214 & + & + \\
\hline Bataviae & bataviae & 0.310 & 0.202 & + & + \\
\hline Canicola & canicola & 0.309 & 0.225 & + & + \\
\hline Celledoni & celledoni & 0.275 & 0.210 & + & + \\
\hline Grippotyphosa & grippotyphosa & 0.432 & 0.408 & + & + \\
\hline \multirow[t]{3}{*}{ Icterohaemorragiae } & copenhageni & 0.320 & 0.467 & + & + \\
\hline & icterohaemorragiae & 0.421 & 0.445 & + & + \\
\hline & lai & 0.208 & 0.089 & + & + \\
\hline Javanica & javanica & 0.179 & 0.225 & + & + \\
\hline Panama & panama & 0.341 & 0.438 & + & + \\
\hline \multirow[t]{2}{*}{ Pomona } & pomona & 0.147 & 0.176 & + & + \\
\hline & proechimys & 0.358 & 0.325 & + & + \\
\hline Pyrogenes & pyrogenes & 0.472 & 0.425 & + & + \\
\hline \multirow[t]{3}{*}{ Sejroe } & sejroe & 0.033 & 0.033 & - & - \\
\hline & hardjo & 0.164 & 0.215 & + & + \\
\hline & wolffi & 0.151 & 0.215 & + & + \\
\hline Shermani & shermani & 0.397 & 0.469 & + & + \\
\hline Andamana & andamana & 0.041 & 0.066 & - & - \\
\hline Semaranga & Patoc & 0.061 & 0.053 & - & - \\
\hline Djasiman & djasiman & 0.154 & 0.105 & + & + \\
\hline Louisiana & louisiana & 0.542 & 0.586 & + & + \\
\hline Ilini & ilini & 0.049 & 0.052 & - & - \\
\hline
\end{tabular}


detect the LipL32 gene in serovar sejroe by PCR resulted unsuccessful (data not shown).

Production of Mabs specific for different serovars of pathogenic Leptospira have been reported by other authors $(10,11)$. Although these MAbs can be used in the development of more specific diagnostic assays, their use is limited to the diagnosis of cases in which that particular serovar is involved. In contrast, the Mabs described here do not suffer from this limitation and can be useful in the development of novel imunodiagnostic tests.

\section{RESUMO}

\section{Anticorpos monoclonais contra uma proteína de membrana externa de Leptospiras patogênicas}

Foram obtidos dois hibridomas secretores de anticorpos monoclonais (MAbs) que reagem com uma lipoproteína (LipL32) da membrana externa de leptospiras patogênicas. Para a produção dos hibridomas, células do baço de camundongos BALB/c, imunizados com LipL32 recombinante (rLipL32), foram fusionadas com células SP2/O-Ag14, selecionadas em meio HAT e testadas em ELISA indireto. Um dos MAbs secretados pelos hibridomas é do isotipo IgG2b e o outro do isotipo IgM. A especificidade dos MAbs foi confirmada em ELISA indireto e immunoblotting usando rLipL32 purificada, Escherichia coli (E. coli) expressando LipL32 e sorovares patogênicos e saprófitas. Os dois MAbs reagiram com a maioria dos sorovares patogênicos e não reagiram com sorovares saprófitas. Os MAbs possuem potencial para uso em testes de diagnóstico de leptospirose.

Palavras-chave: leptospirose, anticorpos monoclonais, LipL32.

\section{REFERENCES}

1. Adler, B.; Murphy, A.M.; Locarnini, S.A.; Faine, S. Detection of specific antileptospiral immunoglobulins $\mathrm{M}$ and $\mathrm{G}$ in human serum by solid-phase enzyme-linked immunosorbent assay. J. Clin. Microbiol. 11:452-457, 1980.

2. Appassakij, H.K.; Silpapojakul, R.; Wansit, R.; Woodtayakorn, J. Evalution of the immunofluorescent antibody test for the diagnosis of human leptospirosis. Am. J. Trop. Med. Hyg. 52:340-343, 1995.

3. Bradford, M.M. A rapid and sensitive for the quantitation of microgram quantitites of protein utilizing the principle of proteindye binding. Anal. Biochem. 72: 248-254. 1976.

4. Brown, J.A.; Lefebvre, R.B.; Pan, M.J. Protein and antigen profiles of prevalent serovars of Leptospiras interrogans. Infect. Immun. 59:1772-1777, 1991.

5. Faine, S.; Adler, B.; Bolin, C.; Perolat, P .Leptospira and Leptospirosis, $2^{\text {a }}$ ed. MediSc, Melbourne, Austrália, 1999, 272 p.

6. Harlow, E.; Lane, D. Antibodies a laboratory manual. United States of America:cold Spring Harbor Laboratory, 1988, 726p.

7. Laemmli, U.K. Cleavage of structural proteins during the assembly of the head of bacteriophage T4. Nature (London) 227:680-685, 1970.

8. Levett, P.N.; Branch, S.L.; Whittington, C.U.; Edwards, C.N.; Paxton, $\mathrm{H}$. Two methods for rapid serological diagnosis of acute leptospirosis. Clin. Diag. Lab. Immunol. 8:349-351, 2001.

9. Lupido, R.; Cinco, M.; Balinzin, D.; Delprete, E.; Varaldo, P.E. Serological followup of patients in a localized outbreak of leptospirosis. J. Clin. Microbiol. 29:107-109, 1991.

10. Surujballi, O; Elmgren, C. Monoclonal Antibodies suitable for incorporation into a competitive enzyme-linked immunosorbent assay (ELISA) for detection of specific antibodies to Leptospira interrogans serovar pomona. Vet. Microbiol. 71:149-159, 1999.

11. Taylor, M.J.; Ellis, W.A.; Montgomery, J.M.; Yan, K.T.; Mcdowell, S.W.J.; Mackie, D.P. Magnetic immuno capture PCR assay (MIPA): detection of Leptospira borgpetersenii serovar hardjo. Vet. Microbiol. 56:135-145, 1997.

12. Towbin, H.; Staehelin, T.; Gordon, G. Eletrophoretic transfer of proteins from polyacrylamide gels to nitrocellulose sheets; procedure and some applications. Proc. Natl. Acad. Sci. U.S.A. 76:4350-4354, 1979. 